\title{
'Tinkering' with tea: science, technology and innovation policies in Tanzania's agricultural research system
}

Allison Loconto and Emmanuel Simbua

\section{Citation}

Loconto, A. and E. F. Simbua (2016). "Tinkering with Tea: Science, technology and innovation policies in Tanzania's agricultural research system." Chapter 9 in the Research Handbook on Science, Technology and Innovation Policy in Developing Countries. S. Kuhlmann and G. OrdonezMatamoros. Cheltenham, UK, Edward Edgar.

\section{Introduction}

Beginning in the 1980s, the Government of Tanzania (GoT) began a long and contentious process of market liberalization that is not yet fully complete. The neoliberal economic theories that underlie the push by the Bretton Woods Institutions towards liberalization in Africa focus on the rhetoric that little state intervention and much foreign direct investment will enable African economies to grow, prosper and 'modernize' (Cooksey, 2011). This same sentiment is seen in popular calls for 'trade not aid' that propose reducing poverty through economic growth, selfreliance and commerce (e.g., Moyo, 2009). What is common to both approaches is that the key to economic growth is seen in a country's ability to harness science, technology and innovation (STI) for policy priorities.

This theoretical positioning of STI within Tanzanian policy is embedded in the second edition of the National Strategy for Growth and Reduction of Poverty (MKUKUTA II), which highlights the government's intent to utilize STI as tools to enhance the performance of its four main growth drivers - agriculture, manufacturing, mining and tourism (GoT, 2010). In the 
agriculture sector, the strategy consists of 'promoting and adopting the use of science and technology in agriculture, including research and development [R\&D] for quality and nutritious food, high value cash crops, fishery and livestock products as well as ICT to provide information on prices, markets, and advisory services' (GoT, 2010, p. 44). Specifically, mechanization, large-scale irrigation and sustainable intensification are some of the areas earmarked for investment and growth (GoT, 2009).

In Tanzania, agriculture is the priority sector for economic growth. It provides employment to over 70 per cent of the population, 45 per cent of the country's gross domestic product (GDP), about 66 per cent of foreign exchange and furnishes the majority of the raw materials for local industries (FAO, 2009). The mainland's main agricultural exports include tobacco, cashew nuts, coffee, cotton, tea, maize, sisal and pulses. It is estimated that Tanzania is fully self-sufficient for food production and has the capacity to be a net exporter of cereals when yields are high. Despite this possibility, about 43 per cent of the population is undernourished placing the country at a higher level of food insecurity than the average for Sub-Saharan Africa which is 33 per cent (FAO, 2009). To date, the rural poverty statistics remain higher than the urban ones, which feeds the policy conviction that agriculture can be used as a vehicle for growth to alleviate poverty (FAO, 2009).

This policy approach is rather typical as it is fully in line with the framework promoted by the Millennium Development Goals (MDGs) and the Poverty Reduction Strategy Papers used by the World Bank to organize development assistance (UNECA, 2013). In fact, Tanzania has accelerated progress on 14 of the 22 MDG indicators and is currently experiencing near 7 per cent growth in its GDP, due to increases in mining and natural gas revenues (UNECA, 2012, 2013). Despite this positive macroeconomic policy picture, Tanzania will still not achieve all of the MDGs 
by 2015 , particularly the goal of reduced poverty. Moreover, despite the rhetoric about agriculture as the main growth-driver, Tanzania has made far better progress, even reaching the MDGs, on primary education, gender equality and health issues (MDGS 2, 3, 4, 6) (GoT, 2011). This suggests that there is a breakdown occurring between policy and practice. The obvious question is why is there this breakdown? However, the purpose of this chapter is not to ask this question. An answer to this question would require more ink than is feasible here. Rather, we focus on the dynamics that are occurring in one sub-sector, the tea sector, in order to better understand how the theories behind STI policy initiatives play out in practice. Therefore, in this chapter we ask, what is being done to fill the gaps?

Kuhlmann et al. (2010) suggest that these gaps might be better understood if we envisage the interactions between innovation practice, policy and theory as systemic dynamics of a social phenomenon. We understand the metaphor of the 'policy dance' as a way to account for the rationales and relevance of STI policy in Tanzania's agricultural research sector, because it demonstrates the pragmatic nature of innovation. According to this metaphor, actors engage in strategic policy decisions and experiments that can affect the direction of innovations - both technological and organizational/institutional. This framework shows us how different actors are mobilized in dynamic processes that are indeed filling the gaps between STI policy and practice. In this chapter, we apply this theoretical framework to the analysis of the Tea Research Institute of Tanzania (TRIT). TRIT, which was established in 1996 as a company limited by guarantee with no share capital, is a national agricultural research institute for the tea sector. TRIT serves the interests of both the private sector and the GoT by supporting the development of both small- and large-scale producers. TRIT receives funding support from donors and from public and private 
sector sources. Until July 2006, it was also funded through a cess (a local government tax) levied on producers, which was a main source of funding for the first decade of TRIT's operation.

TRIT started operations in late 1998. Cranfield University (UK) won the contract to set up the institute and managed it for the first four years. The institute now operates two research stations: Ngwazi (for the southern tea-growing areas) and Marikitanda (for the east and west Usambara tea-growing areas). TRIT's major mission is to improve the productivity and profitability of the whole tea industry, collaborating with all stakeholders. TRIT involves its stakeholders in defining its research priorities and in ensuring that the research programs are demand driven and client oriented. Its governance consists of a board of directors, guided by an advisory panel. The board of directors consists of the executive director of TRIT, representatives from the five main tea-processing companies in the country who comprise the Tea Association of Tanzania (est. 1943), two representatives from the Ministry of Agriculture Food Security and Cooperatives (MAFSC), the executive directors of the Tea Board of Tanzania (TBT) and the Tanzania Smallholder Tea Development Agency and a representative of the European Union Delegation in Tanzania. The advisory panel includes a representative from the private tea companies, a representative of the Tea Research Foundation of Kenya (TRFK), a representative of Sokoine University of Agriculture (SUA), a representative of the MAFSC, a representative of Tea Research Foundation of Central Africa and the executive director of TRIT.

Our data collection followed a participatory approach where the data used in this chapter emerged from participant observations and discussions by the two authors between 2008 and 2013. The second author relied upon his first-hand experience working within the Tanzanian agricultural research system for more than 20 years. This is supplemented by policy document analysis and interviews $(n=5)$ with industry actors by the first author. Our analysis examines the 
policy environment of agricultural research in Tanzania and the role of TRIT within it. Through this analysis we highlight the technology transfer program and illustrate how 'tinkering' is done to create spaces for innovation. We begin by introducing our conceptual framework for analysis.

\section{Dancing and tinkering with innovations}

STI policy scholars have long debated the effectiveness and efficiency of STI policies and practices.

Over the years, and based largely on research in developed countries, scholars have introduced systems thinking (e.g., Edquist, 1997; Lundvall, 1992; Nelson, 1993) into the theory of STI policy and into policy advice for developing countries (Edquist, 2001). The notion of an innovation system encompasses those organizations and institutions that are involved the production, diffusion and use of new knowledge that is 'economically useful' (Kuhlmann, 2001; Lundvall, 1992). This approach suggests that innovation is essentially a collective process that requires a system or network of individuals and organizations in order to turn new knowledge into marketable techniques and products (Akrich, Callon, Latour, \& Monaghan, 2002).

This theoretical advancement allowed scholars to move their analysis outside of single firms, sectors or national policies and into a political space where dynamics of innovation processes and complex relationships became the focus of study. The conceptualization of an 'innovation system' as a heuristic device also meant that there was greater fluidity in determining who was capable of acting, and what might be considered appropriate instruments, in innovation processes (Kuhlmann, 2001). Nonetheless, critiques were raised about the static nature of the descriptions of innovation systems and the lack of focus on micro-level actors and processes (e.g., Kuhlmann, et al., 2010). Its applicability to developing-country contexts were also questioned (STIPRO, 2011). 
The metaphor of the 'innovation policy dance' is meant to capture these dynamics (Kuhlmann, et al., 2010). The metaphor is based on the idea that interactive learning provides the means and space for influencing technological change and innovation. The dance in question consists of three groups of organized actors: those involved in 'innovation practice (I), innovationrelated policy interventions strategies (P), innovation research and theory $(T)^{\prime}$ (Kuhlmann, et al., 2010). As these dancers interact, they play off of each other's cues - at times copying, at other times resisting; sometimes in time to the same music, at other times off step. Through these interactions different combinations of learning might occur (e.g., formal learning, learning by using, learning by interacting and learning by searching). 'In each of these cases, the metaphor attempts to capture a direction of knowledge exchange between the actors. The trick here is actually being able to see these interactions and identify their traces (Latour, 2005).

The participatory approach adopted in this case study offers a way to identify these traces as we focus on the 'tinkering' that is done when different actors dance. The idea of 'tinkering' was first introduced by Jacob (1977) as a way to explain natural selection. He wrote:

In short it [evolution] works like a tinkerer who uses everything at his disposal to produce some kind of workable object ... what these objects have in common is it might as well be of some use'. For what? That depends on the opportunities. (Jacob, 1977, p. 1164)

This concept is taken up by science and technology studies scholars, who utilize 'tinkering' to explain the 'idiosyncratic constellations of equipment, source materials, know-how, etc. (Knorr, 1979, p. 375) that are used in the process of constructing scientific research practices and the practices of care (e.g., Mol, Moser, \& Pols, 2010). Within the metaphor of the I-P-T dance, we characterize tinkering as slight modifications made by one dancer to fit their style to that of their partner. This adjustment can be done by both partners through a reflexive process of intermediation (Callon, 1991). In other words, 'tinkering' within the 'innovation policy dance' is 
pragmatic. There is an element of strategy as decisions are made based on the available opportunities and tools at the actors' disposal, but it is not centrally planned (i.e., official STI policies are quite removed from the innovative activities). Rather, actors engaging in theory, policy and practice modify their approaches and strategies in relation to each other as they try to solve the problems that they face as they try to innovate in the agriculture sector. In the next sections, we focus on the interactions between innovation theory, policy and practice in order to understand how tea industry actors 'tinker' in order to construct I-P-T interactions that respond to the opportunities in the tea sector.

\section{When policy and practice dance, practitioners learn to tinker}

The main linkage between STI policy and practice in agriculture is the focus on the need to increase investment as the main driver of new technologies, economic growth and eventually poverty reduction (Ikiara, 2003). The overarching Agricultural Sector Development Strategy (ASDS, 2001), which is the strategic plan that drives the ASDP, envisions an agricultural sector that, by 2025 , is 'modernized, commercial, highly productive and profitable, utilizes natural resources in an overall sustainable manner and acts as an effective basis for inter-sectoral linkages' (p. 1). The ASDS proposes that the government work towards creating an enabling environment for medium and large-scale investors to make use of the abundant land resources in the country. The ASDS thus promotes private sector-driven modernization and commercialization of the whole agricultural sector by guaranteeing easy access to large parcels of land for large-scale investment in agriculture (Mattee \& Shem, 2006).

While legally, all land in Tanzania is public land and remains vested in the president for and on behalf of all Tanzanian citizens, the Tanzania Investment Act of 1997 allows non-citizens to own land for the purpose of investment. However, this land ownership must be a joint-partnership 
between a Tanzanian citizen and a foreign investor. These reforms also enable long-term leasehold property rights of up to 99 years for foreign companies (which were common practice for tea estates, even during the socialist period). The former press secretary of President Nyerere explained the original intent of these privatization efforts:

The intention there is always to get those companies in the hands of Tanzanians. As many of them as possible, you know. Small shares for everybody. And educate the people of Tanzania on how to join up and buy shares and invest in agriculture. (Huckabee, 2005, p. 5)

The most recent policy initiative, entitled Kilimo Kwanza (Agriculture First, 2009), is an attempt to use agriculture as a driving force for development. Kilimo Kwanza was formulated under the auspices of the multi-stakeholder Tanzania National Business Council (TNBC), which was established in 2001. What differentiates Kilimo Kwanza from prior policies is that it focuses on mobilizing resources from within the government (estimated at 10 per cent of the budget) to add new vigor to those programs initiated under the ASDP (TNBC, 2009). ${ }^{\mathrm{ii}}$ The hope is that these public funds will be matched by the private sector through investment in commercial farming and new technologies that will add value to Tanzania's agriculture sector. The government's 2009/10 budget promised exemption from value added tax (VAT) on processed locally grown tea and coffee and on-farm services - land preparation, cultivation, planting and harvesting. A reduction of the cap on cess from 5 to 3 per cent in 2010/11 was also proposed; this was noted in the World Bank Tea Sector report as a major hurdle for investment (cf. Baffes, 2003). Despite a policy focus on staple food crops, there is rhetoric about maintaining good practices for investment in 'traditional cash crops that farmers are familiar with and have expertise in cultivating' (GoT, 2009). Tea is considered under this latter group of crops.

While the overall Tanzanian policy towards large-scale farming has been characterized as ambivalent (FAO, 2009), this is not reflected in the tea sub-sector. Here, there is a history of large- 
scale plantation agriculture and investment by foreign companies. Since the 1960 s the smallholder sector has grown and there is strong policy support for increasing the capacity of smallholders to be competitive in domestic and international markets. There is also a move towards greater cooperation by private companies with smallholder farmers to introduce new technologies and innovative organizational arrangements. In this example, we discuss how actors 'tinker' in terms of 'learning by using'. Here, learning occurs mostly on the part of practitioners, who learn to dance around policy initiatives in order to invest in organizational innovations in the tea industry.

\section{Learning by using - tinkering with policy in practice}

Tea was introduced in Tanzania by German settlers at the Agricultural Research Station in Amani, Tanga in 1902 (site of the current Marikitanda station). It was grown at Kyimbila in Rungwe District, Mbeya region in 1904. Commercial production began in 1926 and increased considerably after World War II, when the British took over the tea plantations. By 1960 Tanzania's tea production reached 3700 tons of made tea (MT). Before independence, tea was produced in estates which were owned by foreigners and all tea related matters were handled by the then Tanganyika Tea Board. Smallholder tea farming began during the 1960 s - as it was prohibited by law prior to independence. In 1968, the government initiated a full-fledged smallholder tea development program whereby the Tea Ordinance Act (Cap 291) was amended and the Tanganyika Tea Board was replaced with the Tanzania Tea Authority (TTA). All aspects of smallholder tea marketing and trade were turned over to TTA, which assumed a wide array of responsibilities. Rent-seeking behavior was common in the smallholder tea sector throughout this period when six tea-processing factories had been state-owned and operated (Fischer, 2007). This

consisted of very low shares of the market price, received by the TTA, reaching farmers and a general trend where farmers consistently received late payments or no payments at all for their 
tea. The government tried to revive the sector in the early 1980 s by privatizing and rehabilitating two tea estates, which had been nationalized in the 1970s; restructuring the tea board, turning it from a marketing board to a regulatory agency; privatizing the six state-owned tea factories; and revamping public research.

However, the real restructuring only occurred when the government repealed the tea ordinance that established the TTA with the Tea Act No. 3 of 1997 and formed the TBT and the Tanzania Smallholders Tea Development Agency (TSHTDA) (TBT, 2009). Figure 1 shows the institutional structure of the tea industry, which is a multilayered system of organizations that are in constant communication and collaboration, particularly around the negotiation of agricultural workers' wages, smallholder greenleaf prices, extension services, market information and changes in public tea policy.

[Insert Figure 1 here]

\section{Figure 1: Tanzanian Tea Stakeholders}

NB: The linking arrows indicate the direction of relationships where negotiation, sharing of information, resources or control occur between stakeholders.

These policy initiatives had some successes, but there were still many challenges inhibiting growth when the World Bank reported on the tea sub-sector in 2003 (Baffes, 2003). The successes include the complete privatization of the industry, the revitalization of the local blending and packing sector, and rehabilitation of abandoned tea fields. During the liberalization phase, analysts saw challenges to this project in the import and export bans on packed tea and greenleaf, respectively, the taxation structure which was seen to be too complex with excessively high rates, the significant discretionary power of the tea board and ministries and the inadequate 
infrastructure (Baffes, 2003). These challenges meant that the private actors had to develop ways to keep the industry vibrant despite a policy environment that was not fully liberalized. One of the things that they did was collaborate in pushing forward reforms in 2009 that resolved the tax issue and reduced the discretionary power of the tea board, positioning it more in a regulatory and consumer awareness role and funding tea research through private contracts. Nonetheless, there are a few aspects of the original legislation that set the tea industry up as a feasible investment for both local and international private investors. For example, The Tea Act of 1997, which was amended in 2009 into a Tea Industry Act, set a priority for adding value to the greenleaf, and Article 27 of the 1999 Tea Regulation states that 'all green leaf tea produced in Tanzania shall be processed locally'. This commitment has been reinforced with the Kilimo Kwanza initiative, which will strengthen the prohibition of exporting raw materials for processing in other countries. These original commitments and reforms have contributed to the willingness of some companies to invest further in the industry, and thus in this case, policy has successfully been put into practice. The tea sub-sector in Tanzania is now fully privatized and while the planted area is divided evenly between large estates ( $>1000$ hectares) and smallholders ( $<1$ hectare), smallholders contribute less than 30 per cent to total tea production. In total, the tea sub-sector consists of 19 MTprocessing factories owned by 11 companies and smallholder associations and five licensed blending and packing factories.

Because of national restrictions on the export of unprocessed greenleaf, a large portion of the value chain remains in Tanzania. The Tanzanian value chain can be characterized by three key points where value is added: (1) plucked greenleaf from smallholders (ex-farm gate), (2) graded and bulky packaged MT (ex-factory) and (3) blended and retail packaged (ex-blenders \& packers) (Simbua, 2006). These three stages are distinguished further by the number of actors involved as 
tea changes hands and gains value at the end of each stage. The tea-processing factory is considered to be the anchor of the tea value chain: 'a stage where the core competence of the entire tea value chain resides' (Simbua, 2006, p. 189). This stage involves high capital costs, which lowers the competition in a geographic area. Both upstream (greenleaf production) and downstream (marketing and sales) activities are determined by the decisions made at the teaprocessing factory.

It is therefore at the processing stage that most investors enter. Investors purchase processing factories together with large-scale estates. In Tanzania, the five tea packing companies have also invested upstream through joint investments in processing factories and/or estates that provide the majority of the tea that is packed domestically. There are currently three different organizational relationships between tea growers and factories in Tanzania. These relationships are (1) full ownership of growing and processing by a single private company, (2) full ownership of processing by a single-investor company and contracted growing by smallholder farmers and (3) joint shared ownership between a single-investor company and smallholder cooperatives of the processing facility and estate-grown tea, with contracted smallholder production (Loconto \& Simbua, 2012).

These organizational innovations have emerged over the years as investors tried to find ways to negotiate some of the policy restrictions tied to privatization and land ownership. The third option is currently a political favorite as the TBT director general explained, ' $[i] f$... our tea farmers here in Tanzania own their industry, I am sure they will be highly motivated in producing it' (Kimaro, 2009). Even TRIT is involved in promoting this idea, as it sees opportunities for more equitable sharing of value added with the tea farmers. However, in order to avoid a repeat of the TTA experience, TRIT is hoping to be involved in a training capacity through the creation of a type 
of 'tea management training' program whereby smallholders and rural youth could begin working in a TRIT-sponsored factory as a way to learn the business of factory management while staying in the rural areas. Table 1 is a cost scenario TRIT produced in 2009 as part of a proposal for increasing value and expanding the tea sub-sector in Tanzania.

Table 1: Exploring smallholder entry into upstream stages of the value chain

\begin{tabular}{|l|l|c|c|c|}
\hline \multicolumn{5}{|l}{ For each kilogram of MT, assuming the price is 100\% } \\
\hline \multirow{2}{*}{ Sn. } & Components of the MT price & Scenario 1 & Scenario 2 & Scenario 3 \\
\cline { 3 - 5 } & & $\mathbf{( \% )}$ & $\mathbf{( \% )}$ & $\mathbf{( \% )}$ \\
\hline 1 & Factory Capital Costs (Grant or Loan) & 10 & 0 & 0 \\
\hline 2 & Greenleaf Costs (Price to Farmers) & 20 & 20 & 20 \\
\hline 3 & Management Costs & 20 & 20 & 20 \\
\hline 4 & Factory Processing Costs & 30 & 30 & 30 \\
\hline & TOTAL COSTS & $\mathbf{8 0}$ & $\mathbf{7 0}$ & $\mathbf{7 0}$ \\
\hline & Profit before Tax & 20 & 30 & 30 \\
\hline & Tax & 10 & 10 & 10 \\
\hline \multicolumn{7}{|l|}{ Net Profit (and or dividends) } & 10 & 20 & $20 *$ \\
\hline \multicolumn{4}{|l}{ Assuming a factory capacity processing 1300 tons/year MT } \\
\hline
\end{tabular}

Scenario 1 = Joint venture with strategic investor (Loan) for factory;

Scenario 2 = Joint venture strategic investor (Grant);

Scenario 3 = Factory solely owned by smallholder with TRIT support (Grant);

* Net profit to be ploughed back to farmers through GL price

Source: (TRIT, 2009)

This policy push is motivated by the original intent of agriculture privatization previously noted and the practice of tinkering with policy at the local level. According to actors in the tea industry, the political system in Tanzania has a history of both 'nationalizing productive infrastructure' and 'government interference in business affairs. iii As a result, there exists a certain level of cautious awareness by private multinational corporations and local investors who own the majority of the processing infrastructure in the tea industry. One of the responses to this uncertainty has been to involve smallholders as shareholders in these factories. This move was mandatory for the privatized state-owned factories whereby the government reserved 25 per cent of the stakes to smallholders. As of 2013 , only two factories were co-owned by smallholder associations. Katumba and Mwakaleli Tea Factories in Rungwe are owned by the Rungwe 
Smallholder Tea Growers Association (RSTGA, 25\%) and Tanzania Tea Packers Ltd (TATEPA) 75\%) through Wakulima Tea Company (WTC), a joint venture company, while New Mponde factory is owned by Usambaras Tea Growers Association (UTEGA, 25\%) and Lushoto Tea Company. It seems that the involvement of smallholders creates security against public sector interference. In other words, while the majority of shares belong to private or foreign investors, the factories are coowned by local smallholder farmers whose interests are taken into consideration, this is a means to accommodate policy priorities.

For the privately held factories, the share of the crop processed from smallholders is another way to adjust to political uncertainty. Mufindi Tea Company (MTC), for instance, absorbs up to 23 per cent of its factory capacity from smallholders. Such commitment and reliance by the factory on smallholders who in turn receive their payment in a timely manner helps to protect the investment against possible state intervention, which remains a threat smallholders begin to protest. As Unilever absorbs only 5 per cent of the crop from smallholders, this security is not ensured. However, the large-scale job provision in their estates, which provides livelihoods to thousands of families in Mufindi district and the second payments that the company provides to its limited out-growers, earns the company the support of the both the government and surrounding communities (Simbua, 2006). Additionally, all of the foreign-owned tea-processing factories in Tanzania are certified for Ethical Tea Partnership, Fairtrade, Organic or Rainforest Alliance standards (Loconto, 2012). MTC and WTC are certified for all four. These certifications provide additional funds to smallholders and farm workers (through price or social premiums), which further strengthen the relationships between different tea industry stakeholders.

As a result of these different pragmatic responses to policy constraints, direct state intervention in tea production has been very limited. Likewise, the switch from an 'interventionist' 
to a 'regulatory' role by the key public agencies enabled the tea sector to continue to tinker with policy to innovate incrementally. Therefore, while there are tensions between policy and practice, the differences that we observe are a result of tinkering, rather than an obvious failure of theory, government or social capital.

\section{When theory and policy dance, theory leads}

STI policy in Tanzania is much younger than agricultural policy, and despite much STI-driven growth rhetoric, it plays a subordinate role in policy dialogue. The first science and technology policy was approved in 1985 and was most recently updated in 1996 (GoT, 1996). In 2006 a 'Master Plan of Action' for policy implementation was prepared and in 2008 the policy was updated to also include innovation. As of 2011, this policy was not yet approved by the cabinet (UNESCO, 2011). However a national R\&D policy was approved in 2010 and the Tanzanian national system of innovation and STI policy were reviewed in 2012/13 in two separate commissioned studies, and recommendations were made to the Ministry of Communication, Science and Technology.

Officially the mandate of the Ministry of Communication, Science, and Technology, STI policy in Tanzania is managed through the ministry's funding of the Tanzania Commission for Science and Technology (COSTECH). COSTECH is the successor of the Tanzania National Scientific Research Council (established 1968). Established by Act of Parliament No. 7 of 1986, it became operational in 1988 and has the mandate of advising government on STI policy, of coordinating and promoting research and technology development activities in the country and of popularizing and disseminating information about STI (COSTECH, 2013). The national STI infrastructure has mushroomed over the past 20 years, with semi-public R\&D institutes in most economic sectors: agriculture and livestock (30), industry and energy (9), medicine and public health (6), natural 
resources (4) and universities (28). ${ }^{\vee}$ As a result, much of COSTECH's attention is focused on coordinating and not on advising government on policy.

Given the importance of the separate economic sectors of society in the political arena, the focus of the 1996 policy, and its implementation strategy, is on strengthening the coordination aspects between the sector-focused research institutes and COSTECH. In their 2011 strategy document, UNESCO comments that:

Weak linkages between the education and research institutions and the private sector, coupled with the inability of the agencies involved to commercialize their research and development (R\&D) and innovate products, mean that Tanzania continues to spend funds for research that does not provide any immediate valuable outcomes to its citizens.

(UNESCO, 2011, p. 15)

This assessment by UNESCO points to a specific gap in the linkage between national-level policy and research implementation. It suggests that there are many missteps between $\mathrm{T}$ and $\mathrm{P}$ actors, and the coordination mission of the policymakers seems to be failing. However, this suggestion requires closer scrutiny. Therefore, in the following paragraphs, we explain how formal learning dominates the T-P dance. The caveat here is that the international research community leads the domestic one.

\section{Formal learning - the international influence}

International evaluations of Tanzanian STI systems in the late 1990s and early 2000s consistently reported underfunding and a dependency of the systems on donor funds (Anandajayasekeram \& Martella, 1999; Gaillard, 2003a, 2003b). Foreign donor funding in Tanzania contributes approximately 70 per cent of the R\&D expenditure in Tanzania (Madikizela, 2007). The public international funding for research between 1990 and 2000 came from (in order of importance) Norway, Sweden, Finland, Germany, the Netherlands, Switzerland and the World Bank. These funds were given solely to the University of Dar-es-Salaam and Sokoine University of Agriculture. 
Interestingly, between 2004 and 2007, the Royal Dutch Government applied the concept of National Innovation Systems to a health technology policy support program in the country (ATPS, 2007). The purpose of this project was to encourage formal learning for researchers and health practitioners on the innovation systems policy framework. A similar training was held by the World Bank in 2010, where TRIT was a participant. The focus on teaching innovation systems theory to researchers has been met with critique by Tanzania policy analysts, who claim that it is too dominated by Northern political contexts and constructs (STIRPO, 2011). In a study that followed up winners of COSTECH's Tanzania Awards for Scientific and Technological Achievement, Diyamett and Mabala (2007) astutely conclude that:

For developed countries with advances in technology, there is little problem in the usual coupling between science and technology; and there is therefore some appreciable degree of complementarities between university science and technology in the productive sector. For poor developing countries, however, a big dichotomy exists between science pursued at the universities and technology. While science and the scientific community is one and global, scientists in poor countries therefore have to be at par with their colleagues worldwide, technology is local, and unfortunately at a very low level compared to contemporary science. (p. 18)

We see examples of the global nature of science in the case of TRIT. TRIT works mostly at two levels, locally with small, medium and large tea farmers in technology transfer and internationally with tea research scientists. Kenyan and Malawian researchers sit on TRIT's advisory panel and there is active collaboration between these research institutes. For example, TRIT worked with TRFK in Kenya to conduct field trials and eventually released for commercial use four new tea clones ${ }^{\mathrm{vi}}$ in Tanzania (TRIT, 2013a). TRIT and four researchers from the Rwanda tea industry trained at TRIT were requested to participate in the review of the current status of tea research institutes in Rwanda, Uganda, Kenya and Tanzania, and to provide recommendations for future collaboration. ${ }^{\text {vii }}$ TRIT is also active in the Intergovernmental Group on Tea, where they 
engage in discussions with researchers in Sri Lanka over best practices in smallholder tea production (see: Simbua \& Loconto, 2010).

Indeed, the global science perspective is seen by some analysts as a 'success' of the STI policy, as measured by publications in the Institute for Scientific Information database. The University of Dar-es-Salaam and Sokoine University are the first (995 publications) ${ }^{\text {viii }}$ and third (222 publications) top producers, respectively, in the 2001-07 period (Madikizela, 2007). ${ }^{\text {.x }}$ With a yearly average of about 350 publications, Tanzania is the second highest producer of research in the South African Development Community. Tanzania's agricultural research tradition is reflected by the relatively high production of publications by Sokoine University. TRIT is even included in the list of major performers in agricultural research (Madikizela, 2007).

This focus of STI policy on international dynamics is not without critique. Diyamett and Mabala (2007) argue for making STI more responsive to Tanzanian societal needs. These observations point to some of the reasons why there are missteps in the T-P dance. Ogbu (2004) argues that the fault lies in the theory. He argues that most policies are written by neoclassical economists, who are technological and market determinists, believing that markets will drive and shape innovation to the benefit of society. Tanzania's history does not fully comply with this theory (Meertens, 2000). As a result, the theory blinds policymakers from constructing national STI systems that focus on the existing networks of actors in R\&D institutions (both public and private) and those in industry (Ogbu, 2004). Regional research coordination was suggested as far back as 1999 (Anandajayasekeram \& Martella, 1999), but has not been systematically taken up in national STI policy. This represents a tension between the theoretical rationale for Tanzania to be internationally competitive in science and the policy pressures for technology. 
In effect, there is a government failure in the Tanzanian system. As policy focuses on theory-driven STI systems, the national capacity to keep up with that focus is lacking, due to funding, competence and institutional inertia that inhibit the ability to imagine possibilities beyond theoretical prescriptions (Aubert \& Wanga, 2007; Ogbu, 2004). The Science, Technology and Innovation Policy Research Organization (STIPRO), the only STI policy think tank in Tanzania, argues that 'In the absence of such [policy research] organizations, and therefore scarce information that support policy processes, government practice has been to commission [a] group of individuals to carry out studies in the event a need for policy change, or enactment of a new policy arise' (STIRPO, 2011, p. 3). The former executive director of TRIT was called upon at the occasion of the Kilimo Kwanza policy initiative and TRIT reports dialogue with COSTECH only on an ad hoc basis. ${ }^{x}$ Meanwhile, stakeholder consultations are beginning to be conducted on development policy agendas (UNDP, 2013). This has not been a consistent approach used to develop the STI or agricultural research policy, particularly during the period of liberalization when funds for agricultural research were severely cut (Madaya, Nuwagaba, \& Mwesigwa, 1999).

In line with the above critiques, the national system has been criticized for having very few linkages between the COSTECH-recognized institutes and the productive sector (Mwamila and Diyamett, 2006). This is indicative of the high level of fragmentation in the STI system, yet this fragmentation means that some sub-sectors perform better than others. We examine these interactions in the next section, as we explore the T-P dance with a case study from TRIT.

\section{Theory and practice dance a two-step}

Within the broader political movement towards liberalization, most of the production, processing and marketing functions have been assigned to the private sector while the GoT has retained regulatory and public support functions (FAO, 2009). Since the Economic Recovery Program of 
1986, the GoT introduced various policy reform measures intended to enhance economic growth and development. Practical implications of this approach are the promotion and development of innovation systems by policymakers, which are in tension with a rising promotion by practitioners for innovative clusters (Mwamila, Trojer, Diyamett, \& Temu, 2004; Porter, 1990). This sub-system approach has been popular by policy analysts in Tanzania, as the fragmentation of knowledge production and institutions into diverse sectors and sub-sectors do not align well with a national STI policy strategy (Diyamett, 2004). Diyamett promotes a focus on technology and incremental innovations, as fundamental science remains mostly in laboratories and the transformation process of this knowledge is not easily done through the current institutional setup. We argue that there are examples of incremental innovations in the tea sector. To explain how these work, we discuss how TRIT is learning by interacting and learning by searching. This backward-forward exchange is where we see tinkering in tea.

\section{Interacting and searching, a two-way learning process}

A critique of other sectors of the Tanzanian economy is that industrial research institutes have largely ignored supply chains (Mjimba, 2011; Perkins \& Robbins, 2011). This is very difficult to do in an export-driven sector of tea and its value chain that was previously explained. Tea is highly integrated into GVCs and one of the largest global tea blenders owns and operates tea estates in Tanzania (Loconto, 2012). This means that many of the innovations in use in the global tea sector eventually find their way into Tanzania and transmission to smallholders is facilitated by TRIT.

TRIT is made up of the following research programs: crop improvement, crop water management, soil fertility management and technology transfer. Research on water and fertilizer use, and clonal evaluation is conducted in laboratories and field trials. A state-of-the-art soil and plant analytical laboratory is functioning and provides analytical services on a commercial basis. 
TRIT's research is geared towards solving practical problems facing growers. For example, on-farm fertilizer trials are ongoing in Rungwe and Muheza districts (Ndunguru, 2007) and in Mufindi TRIT has on-farm trials of drip irrigation to determine its feasibility for small-scale farms (Kigalu, 2009).

This range of activities exemplifies TRIT's learning by searching.

Through these practices, TRIT developed a framework for extension advice based on the results of field trials on both small-scale and large-scale farms (Table 2).

Table 2: Effect of low input use and poor field management on tea yields

\begin{tabular}{lll}
\hline & $\begin{array}{l}\text { Effect of constraint on } \\
\text { potential yield (kg MT/ha) }\end{array}$ & Resulting yield (kg MT/ha) \\
\hline No constraint & 0 & Potential Yield =6080 \\
Drought & -1520 & 4560 \\
Nutrition & -3040 & 1520 \\
Vacancies & -300 & 1220 \\
Poor harvesting & -610 & 610 \\
\hline
\end{tabular}

Source: (Ndunguru, 2007)

The TTP is a way to ensure that appropriate technologies are developed, tested and delivered to stakeholders. TTP is responsible for disseminating research results and ensuring that TRIT staff operate within a farming systems approach to research. According to TRIT, the aim of the program is

to develop and promote technologies that lead to increases in the productivity and profitability of tea particularly from smallholders and hence to improve the livelihood of rural people especially women and also to increase Tanzania's foreign exchange earnings (including a demand driven farmer training program for empowering growers to use appropriate and efficient tea production techniques). (TRIT, 2013b)

Initially, this program was funded by the UK Government through the Department for International Development, but currently it is supported through the European Union. The theoretical background of the TTP relies on Roger's (1983 [1962]) linear diffusion of innovation model, whereby users either adopt or don't adopt the technology that is developed by experts. 
However, as the program expanded, TRIT began to listen to users and promote appropriate technologies. Interactions between researchers and tea producers showed that farmers' ability to produce greenleaf tea could be improved by the adoption of research outputs like new clones or new cultivation techniques, provided that (1) farmers are aware of their existence and of their application; (2) these techniques are effective; (3) farmers can access the required inputs; and (4) the adoption is profitable. These lessons fed back into TRIT support and resulted in the mobilization of small-scale farmers into village-based nursery schemes for producing seedlings. Since 2001, over 3500 groups (comprising of 13000 members) were established and managed to raise over 62 million plants (TRIT, 2013b). Improvements to this program are constantly made, as users provide input to TRIT regarding the success of these programs. For example, in response to a user request, clonal mother bushes were planted in blocks closer to users' villages to ensure that good quality clonal materials are readily available when needed. This type of tinkering between theory and practice is only possible when researchers are actively involved in material sites of practice.

Emerging from the lessons learned and disseminated through the TTP, TRIT has been contracted to provide extension services to the WTC since 2003. This arrangement, whereby a private company approaches a research institute to provide services at cost, is an organizational innovation that links researchers, extension services, farmers, transporters, processors and markets. The TRIT extension unit is responsible for providing farmers with technical support to enable them to attain optimal production potential; achieve effective harvesting systems that will provide greenleaf of acceptable quality within the given plucking schedule; facilitate the high volume collection of greenleaf in order to ensure efficiency of the transportation systems; facilitate correct and timely payments to farmers for their greenleaf; and coordinate field 
activities, assessment of input needs and supervision of distribution and subsequent use by farmers. This is an integrated approach linking production, transportation, processing and marketing in a small geographic space. All these work together, albeit under different organizations (e.g., RSTGA controls production, WTC controls processing and marketing, and Jilanjo is contracted by WTC to provide transportation).

The commercial extension program provides a good example of tinkering between theory and practice. There is currently a concern about labor shortage in the Rungwe tea fields, which results in delayed plucking of tea bushes and overgrowth of tea fields. It is one of the most limiting factors for the productivity of small-scale tea farms. Labor shortage for smallholders is attributed to competition with estates and the reality that several farming activities must share the available labor. Since there is low involvement of youth in tea production in some areas, and the fact that it is a woman-dominated activity in others, means that tea plucking adds an additional labor demand to an already overloaded work schedule. Moreover, the women also complain of calluses and hand sores, due to plucking the tea by hand, which further limits the amount of time they are willing to spend plucking. ${ }^{\mathrm{i}}$

Experience from other countries (Sri Lanka, India and Kenya) show the cost of mechanical plucking is as low as one tenth of hand plucking. Moreover, mechanical plucking has a capacity of plucking seven to eight times as much as manual. Researchers find the use of shears increases the plucking average with a net decrease in cost of production when compared to hand plucking (Mhagama, 2009). Some concern has been raised over the quality of hand plucked versus machine plucked tea as studies have shown that the quality of hand plucked tea is better than mechanically plucked tea, but the difference is not highly significant (Mhagama, 2009). Moreover, there is some evidence that tea obtained from a continuously sheared field over a prolonged period of time is 
superior to the hand plucked tea. ${ }^{\text {xii }}$ Tanzania's own experience with mechanical harvesting in the Njombe region produces greenleaf of a higher standard than hand plucked tea. In this case, the speed with which mechanically harvested tea is delivered to the factory becomes a greater determinant of the quality of processed tea. Based on this background research and grassroots concerns, the TRIT extension program began to trial the use of plucking shears, which have proved successful on estates in Northern Tanzanian, India, and in Taiwan where 80 per cent of smallholder production is mechanized. Following a two-phase trial period, 2000 pieces were ordered following a massive demand from smallholders, who learned of the opportunity through the extension officers and by word of mouth. Formal training was conducted prior to supplying the 2000 pieces, followed by routine monitoring of quality, productivity, fertilizer application and bush health by the extension team (Mhagama, 2009).

The feedback loop between theory and practice was fundamental to the program's success. First, the changes in plucking rounds needed to be coordinated by the WTC factory and greenleaf transportation company; this was effectively adjusted to fit the new plucking schedules. Second, mechanical harvesting resulted in excessive removal of nutrients from the soil as nitrogen fixes in the leaves of the bushes, which are removed at weekly intervals. Therefore, nutrients in the soil should be in adequate amounts and balanced to ensure a sustainable yield increase. The TRIT research team intervened with the extension team to monitor yield responses to different levels and types of fertilizer in order to establish the optimal and feasible amounts of fertilizers for mechanically harvested tea on small farmer plots. This information was fed back through the extension system to the farmers who have chosen the mechanized plucking schedules. Practical results from this dance are a five-fold increase in productivity (Rowland, 2008). In line with the increase of greenleaf production, the price per kilogram also increased, from TZS 72.50 in 2001 to 
TZS 196 in 2012. ${ }^{\text {xiii }}$ The quality of tea has improved: WTC led Tanzanian tea in price at the auction in Mombasa, Kenya in 2010.

The opportunities for tinkering were found in the dialogue between $\mathrm{T}$ and $\mathrm{P}$ actors who were able to identify a problem with an appropriate solution, but more importantly it was the organization of the greenleaf pickup and timely payment of farmers that enabled success. Indeed, it seems that tinkering was fundamental to stimulating the learning by interacting processes whereby TRIT mediated between theory and practice. This example illustrates how the tea subsector is operating very much within its sector-specific silo, innovating through its existing networks, and focusing on technologies that are appropriate for their clients, but are not considered within the mechanization program by policymakers.

\section{Conclusions}

In this chapter we argue that imagining activities in tea research as 'tinkering' helps to explain the learning processes and gaps in STI policy. We illustrate this by detailing how the tea industry tinkers with investment in the sector in a process of learning by using; how international networks influence formal learning; and how learning by interacting produces incremental innovations in practice.

By analyzing these three dances, we show that there is a dominance of theory, but not a dominance of theoretically-driven results. Rather, the actors are tinkering with the opportunities at their disposal to create spaces for progress on policy indicators that do not always align with the theory that drives them. For example, the institutional framework for agricultural research is separated along the lines of core export commodities while the extension mandate is organized according to political districts under a separate ministry. STI policy remains at a national level and works closely with the university system, but not the agricultural research institutes. In field 
stations and through field applications, interactions between the two sets of policies remain isolated in their institutional structures. In other words, the STI landscape is highly fragmented and the tinkering that occurs allows only incremental innovation, not necessarily in line with STI policy priorities.

As a result, there seems to be a government failure. This suggests that the practices of technology adoption and innovation are not taken up in systematic ways - particularly within the rhetoric of investment and growth. The existing agricultural research institutions provide the basic infrastructure for STI policy, but it is increasingly apparent that opportunities to mobilize expertise in innovative collaborations with the private sector must be pursued by the research institutes themselves, not least because of funding shortages. Indeed the government failure illustrated in this case is actually a resource for new collaborations.

In sum, in Tanzania part of the problem is indeed a lack of money. However, this does not fully explain the complexity of interactions between theory, policy and practice, nor does it tell us what is being done to fill the gaps. We argue that there are examples of government failure in this sector. By recognizing where these failures are, we can help to explain situations of failure, where either 'partner' could trigger a change within the framework of the 'innovation policy dance' metaphor (Kuhlmann, et al., 2010). However, it may be more appropriate to speak of tensions, rather than failures. Indeed, tensions between science and technology, tensions between different types of innovation, and tensions between policy, theory and practice characterize the STI landscape. By drawing upon insights from the notion of tinkering, we contribute to the critiques raised within Tanzania. It seems to us that national STI policy is a gloss. By positioning policy around STI, it creates the imperative for policymakers to ask 'where' it can be found. However, as some critics argue, we should be asking instead 'what is STI?' When we change the question we 
can begin to understand where aspects of this construct might be found, who is involved in implementing them, and how they might hold together in a more robust policy framework that is appropriate for the Tanzanian context.

\footnotetext{
'See Table 1.2 in Kuhlmann et al. (2010) for a description of each of these types of learning.

ii This is an increase from 6.2 per cent dedicated in the 2009 budget. In the 1990s, during the height of neoliberal reforms, only 2.9 per cent of the national budget was dedicated to agriculture.

iii Interviews with industry stakeholders in 2009-10 repeatedly made this point.

${ }^{\text {iv }}$ This company has been heralded by the World Bank as an excellent example of well-directed venture capital and technical assistance (World Bank, 2000).

${ }^{\vee}$ For an overview of the institutional and policy environment for STI, see (Gaillard, 2003b).

${ }^{v i}$ In tea, clones refer to the cuttings taken from one bush that have been replanted to form new bushes.

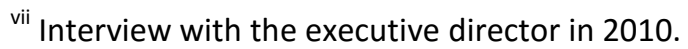

viii Up from 266 between 1991-97(Narváez-Berthelemot, Russell, Arvanitis, Waast, \& Gaillard, 2002)

${ }^{\text {ix }}$ The second highest producer with 408 publications was Muhimbili University, College of Medical Science, which focuses on contagious and non-contagious diseases.

${ }^{x x}$ Interview in 2010 and personal communication in 2013.

${ }^{\mathrm{xi}}$ Interview with RSTGA in 2009.

${ }^{x i i}$ This is a highly contentious debate with evidence supporting both arguments.

xiii The 2009 price was 135 TZS/kg. This was far above the national average. In 2012, following lobbying by the Chai Project (Gatsby Trust and Wood Family Trust) the national minimum price was negotiated at 196 $\mathrm{TZS} / \mathrm{kg}$.
}

References 
Akrich, M, Callon, M, Latour, B, \& Monaghan, A. (2002). The key to success in innovation Part I: The art of interessement. International Journal of Innovation Management, 06(02), 187206.

Anandajayasekeram, P, \& Martella, DR. (1999). Evaluation of agricultural research in Eastern, Central, and Southern Africa. Knowledge, Technology \& Policy, 11(4), 13-41.

ATPS. (2007). ATPS Phase VI Strategic Plan 2008-2011. Science and Technology Policy Research Today for Sustainable Development Tomorrow. Nairobi, Kenya: African Technology Policy Studies Network (ATPS).

Aubert, J-E, \& Wanga, G. (2007). Innovation in Tanzania: Insights, Issues and Policies. In A. Utz (Ed.), Sustaining and Sharing Economic Growth in Tanzania. Washington DC: The World Bank.

Baffes, J. (2003). Tanzania's Tea Sector: Constraints and Challenges. Washington, DC: World Bank. Callon, M. (1991). Techno-economic networks and irreversibility. In J. Law (Ed.), A Sociology of Monsters: essays on power, technology and domination (pp. 132-163). London: Routledge.

Cooksey, B. (2011). Marketing Reform? The Rise and Fall of Agricultural Liberalisation in Tanzania. Development Policy Review, 29, s57-s81.

COSTECH. (2013). Tanzania Commission for Science and Technology: About Us Retrieved 15 September, 2013, from http://www.costech.or.tz/?page id=1593

Diyamett, B. (2004). The concept of technological innovation: Theoretical overview and some practical implications for Africa. In B. L. Mwamila, L. Trojer, B. Diyamett \& A. Temu (Eds.), Innovation systems and innovative clusters in Africa. Regional Conference, February 18-20, 2004. Bagamoyo, Tanzania: Sida. 
Diyamett, B, \& Mabala, R. (2007). From Inventors to Innovators: An Investigation into Individual Inventors in Tanzania ATPS Special Paper Series No. 36. Nairobi, KE: African Technology Policy Studies Network (ATPS).

Edquist, C. (1997). Systems of innovation : technologies, institutions, and organizations. London ; Washington: Pinter.

Edquist, C. (2001). Systems of innovation for development. Competitiveness, innovation, and learning: Analytical framework. Geneva: UNIDO World Industrial Development Report.

FAO. (2009). Agricultural Sector Reforms in Tanzania: Perspectives from within Project Report "Strengthening National Capacity in Agricultural Trade and Trade Negotiations" (GCP/URT/056/IRE). Rome: Food and Agriculture Organization of the United Nations.

Fischer, PV. (2007). Rent-Seeking, Institutions and Reforms in Africa: Theory and Empirical Evidence for Tanzania. Dordrecht: Springer.

Gaillard, J. (2003a). Overcoming the scientific generation gap in Africa: an urgent priority. Interdisciplinary Science Reviews, 28(1), 15-25.

Gaillard, J. (2003b). Tanzania: A Case of 'Dependent Science'. Science Technology \& Society, 8(2), 317-343.

GoT. (1996). The National Science and Technology Policy for Tanzania. Dar-es-Salaam: United Republic of Tanzania.

GoT. (2009). Kilimo Kwanza Resolution and Ten Pillars. Dodoma, Tanzania: United Republic of Tanzania.

GoT. (2010). National Strategy for Growth and Reduction of Poverty II Dar-es-Salaam: United Republic of Tanzania. 
GoT. (2011). Tanzania. Country Report on the Millennium Development Goals 2010. Dar-esSalaam: United Republic of Tanzania and the United Nations Development Fund in Tanzania.

Huckabee, B (Writer). (2005). Paul Sozigwa Interview, Heaven On Earth: The Rise and Fall of Socialism. USA: New River Media

Ikiara, MM. (2003). Foreign Direct Investment (FDI), Technology Transfer, and Poverty Alleviation: Africa's Hopes and Dilemma ATPS Special Paper Series No. 16. Nairobi, KE: African Technology Policy Studies Network (ATPS).

Jacob, F. (1977). Evolution and Tinkering. Science, New Series, 196(4295), 1161-1166.

Kigalu, JM. (2009). Evolution of research on irrigation of tea in Tanzania: overhead sprinkler and drip systems. Paper presented at the TRIT Open Day Scientific Conference - Towards smallscale irrigation technologies for the Tanzanian smallholder tea sector, Ngwazi Research Station, Mufindi, Tanzania.

Kimaro, S. (2009, Thursday 10 September 2009). Tea industry ownership patterns discouraging tea growers, THISDAY, p. 3.

Knorr, KD. (1979). Tinkering toward Success: Prelude to a Theory of Scientific Practice. Theory and Society, 8(3), 347-376.

Kuhlmann, S. (2001). Future governance of innovation policy in Europe - three scenarios. Research Policy, 30(6), 953-976.

Kuhlmann, S, Shapira, P, \& Smits, R. (2010). Introduction. A Systemic Perspective: The Innovation Policy Dance. In R. Smits, S. Kuhlmann \& P. Shapira (Eds.), The theory and practice of innovation policy : an international research handbook (pp. xiii, 481 p.). Cheltenham, UK ; Northampton, MA: Edward Elgar. 
Latour, B. (2005). Reassembling the social : an introduction to actor-network-theory. Oxford ; New York: Oxford University Press.

Loconto, A. (2012). Value Chains and Chains of Values: Tracing Tanzanian Tea. In F. Arfini (Ed.), Local Agri-Food Systems in a Global World: Market, Social and Environmental Challenges (pp. 195-214). Newcastle upon Tyne, UK: Cambridge Scholars Publishing.

Loconto, A, \& Simbua, E. (2012). Making Room for Smallholder Cooperatives in Tanzanian Tea Production: Can Fairtrade Do That? Journal of Business Ethics, 108(4), 451-465.

Lundvall, B-Å. (1992). National systems of innovation : towards a theory of innovation and interactive learning. London: Pinter Publishers.

Madaya, P, Nuwagaba, A, \& Mwesigwa, D. (1999). The Impact of Economic Liberalisation Policies on Technologies in Enterprises Processing Agricultural Produce: The case of Kampala (Uganda) and Dar-es-Salaam (Tanzania) ATPS Working Paper No. 14. Nairobi, KE: Afrian Technology Policy Studies Network.

Madikizela, M. (2007). 12. TANZANIA. In sarua (Ed.), A baseline study on science and technology and higher education in the SADC region (pp. 184). Joannesburg, South Africa: Southern African Regional Universities Association.

Mattee, AZ, \& Shem, M. (2006). Ambivalence and contradiction: A review of the policy environment in Tanzania in relation to pastoralism Issue Paper No. 140. London: International Institute for Environment and Development (IIED).

Meertens, B. (2000). Agricultural performance in Tanzania under structural adjustment programs: Is it really so positive? Agriculture and Human Values, 17(4), 333-346.

Mhagama, JP. (2009). Extension \& Technology Transfer Perspective: Potentials for the emerging technologies for the Tanzania Smallholders Tea Production Systems; Irrigation \& 
Mechanised Harvesting. Paper presented at the TRIT Open Day Scientific Conference Towards small-scale irrigation technologies for the Tanzanian smallholder tea sector, Ngwazi Research Station, Mufindi, Tanzania.

Mjimba, V. (2011). The Nature and Determinants of Linkages in Emerging Minerals Commodity Sectors: A Case Study of Gold Mining in Tanzania. MMCP Discussion Paper 7. Open University. Milton Keynes, UK.

Mol, A, Moser, I, \& Pols, J. (2010). Care in Practice: On Tinkering in Clinics, Homes and Farms. Bielefeld, Germany: Transcript Verlag.

Moyo, D. (2009). Dead Aid: Why Aid Is Not Working and How There Is a Better Way for Africa: Farrar, Straus and Giroux.

Mwamila, BL, Trojer, L, Diyamett, B, \& Temu, A (Eds.). (2004). Innovation systems and innovative clusters in Africa. Bagamoyo, Tanzania: Sida.

Narváez-Berthelemot, N, Russell, J, Arvanitis, R, Waast, R, \& Gaillard, J. (2002). Science in Africa: An overview of mainstream scientific output. Scientometrics, 54(2), 229-241.

Ndunguru, BJ. (2007). Experiences in technology transfer: The case of Tea Research Institute of Tanzania (TRIT). International Journal of Technology Management \& Sustainable Development, 6(3), 245-251.

Nelson, RR. (1993). National innovation systems : a comparative analysis. New York: Oxford University Press.

Ogbu, O. (2004). How can innovation systems and innovative clusters be used to develop Africa? Technopolicy Brief 10. Nairobi, KE: African Technology Policy Studies Network. Perkins, D, \& Robbins, G. (2011). The Contribution to Local Enterprise Development of Infrastructure for Commodity Extraction Projects: Tanzania's Central Corridor and 
Mozambique's Zambezi Valley. MMCP Discussion Paper 9. Open University. Milton Keynes, UK.

Porter, ME. (1990). The competitive advantage of nations. New York: Free Press.

Rogers, EM. (1983 [1962]). Diffusion of Innovations. New York: Free Press.

Rowland, P. (2008). TATEPA and RSTGA - A Successful Privatisation in Tanzania: The Progress of Wakulima Tea Company 9th October 2008 Presentation to H.E. President Kikwete. Tukuyu, Tanzania: Wakulima Tea Company.

Simbua, EF. (2006). The role of the Smallholder Tea Based Production Systems in the Tanzanian Tea Value Chain. Paper presented at the Annual Meeting and Scientific Conference of the Agricultural Economists Society of Tanzania (AGREST), 14 - 17 August 2006, Morogoro Hotel, Morogoro Tanzania.

Simbua, EF, \& Loconto, A. (2010). Sustainability of smallholder tea production in the United Republic of Tanzania. (CCP:TE 10/4). Rome: Food and Agriculture Organization of the United Nations.

STIPRO. (2011). ATPS-Tanzania: Rationale, Past, Present and Future Strategies. Dar-es-Salaam, TZ: Science, Technology and Innovation Policy Research Organization (STIPRO).

STIRPO. (2011). ATPS-Tanzania: Rationale, Past, Present and Future Strategies. Dar-es-Salaam, TZ:

Science, Technology and Innovation Policy Research Organization (STIPRO)

TBT. (2009). Performance of the Tea Industry in Tanzania. Dar es Salaam, TZ: Tea Board of Tanzania.

TNBC. (2009). 6th TNBC Meeting. Dar es Salaam: Tanzania National Business Council. TRIT. (2009). TRIT Annual Report 2008/2009. Dar es Salaam: Tea Research Institute of Tanzania. 
TRIT. (2013a). 4 NEW TEA CLONES IN TANZANIA Retrieved 15 September, 2013, from http://www.trit.or.tz/research-programmes/4-new-tea-clones-in-tanzania/

TRIT. (2013b). Technology Transfer Program-TTP Retrieved 15 September, 2013, from http://www.trit.or.tz/research-programmes/technology-transfer/ UNDP. (2013). United Republic of Tanzania Post 2015 Development Agenda Consultations: Key messages (pp. 1-6). Dar-es-Salaam: United Nations Development Fund in Tanzania.

UNECA. (2012). Sustaining Economic Growth and Development in Turbulent Times: Tracking Progress on Macroeconomic and Social Developments in the Eastern Africa Region 201112. Addis Ababa, Ethiopia: United Nations Economic Commission for Africa, Sub-regional Office for Eastern Africa.

UNECA. (2013). Food security in Africa: Issues, challenges and lessons Assessing Progress in Africa toward the Millennium Development Goals: MDG Report 2013. Addis Ababa, Ethiopia: United Nations Economic Commission for Africa, African Union, African Development Bank Group, and the United Nations Development Fund.

UNESCO. (2011). UNESCO Country Programming Document 2011-2015: United Republic of Tanzania. Dar-es-Salaam: United Nations Educational, Scientific and Cultural Organization. World Bank. (2000). Tea-time in Tanzania. SME FACTS: News about World Bank Group Small and Medium Enterprise Initiatives, Vol. 1(Issue 11). 